\title{
ANALISIS DATA CITRA LANDSAT UNTUK PEMANTAUAN PERUBAHAN GARIS PANTAI KOTA BENGKULU
}

\author{
Oleh : \\ Silvy Syukhriani, Eko Nofridiansyah, Bambang Sulistyo \\ Program Studi IImu Kelautan Fakultas Pertanian Universitas Bengkulu \\ Email: ekonofridiansyah@unib.ac.id \\ Received March 2017 Accepted April 2017
}

\begin{abstract}
ABSTRAK
Penelitian ini bertujuan untuk menganalisis perubahan garis pantai Kota Bengkulu dengan teknologi penginderaan jauh menggunakan data citra Landsat, berdasarkan data multi temporal dengan teknik analisa visual dan digital antara tahun 2006 sampai tahun 2015. Garis pantai adalah batas antara daratan dan lautan yang mempunyai bentuk bervariasi dan dapat berubah dari musim ke musim. Tujuan dari penelitian ini untuk mempermudah dalam memantau perubahan garis pantai Kota Bengkulu dengan teknologi penginderaan jauh menggunakan data citra Landsat-TM, Landsat-7 ETM+ dan Landsat-8 OLI selama 10 tahun dari tahun 2006 sampai tahun 2015. Metode yang digunakan yaitu dengan melakukan digitasi dan tumpang susun (overlay) data citra sehingga diperoleh data perubahan garis pantai, serta pengamatan lapangan sebagai verifikasi hasil. Dari penelitian ini didapatkan bahwa rata-rata luas perubahan garis pantai Kota Bengkulu mengalami abrasi sebesar 19,41 hektar/tahun dan rata-rata luas perubahan garis pantai Kota Bengkulu yang mengalami sedimentasi sebesar 18,7 hektar/tahun. Adapun daerah yang mengalami perubahan garis pantai setiap tahunnya yaitu Muara Sungai Hitam, Muara Kualo, Muara Sungai Jenggalu dan Pelabuhan Pulau Baai. Perubahan Garis Pantai Kota Bengkulu dapat terjadi karena adanya faktor alamiah dan faktor manusia (Antropogenik).
\end{abstract}

Kata Kunci : Garis pantai, penginderaan jauh, citra landsat, abrasi, sedimentasi.

ABSTRACT

The research aimed to analyze the changes in the coastal line town of Bengkulu with remote sensing technology using Landsat imagery data, based on data from multi-temporal with visual and digital analysis techniques between 2006 and 2015. The coastal line is the boundary between land and sea has varied forms and can change from season to season. The purpose of this research is to facilitate the monitoring of coastal line change of Bengkulu City with remote sensing technology using image data of Landsat-TM, Landsat-7 ETM + and Landsat-8 OLI for 10 years from 2006 to 2015. The method used is to perform digitization and overlaying (overlay) of image data in order to obtain the data changes in the coastal line, as well as verification of the results of field observations. From this study found that the average area of coastal line change of Bengkulu City is abration of 19.41 ha / year and the average area of coastal line change sedimentation of Bengkulu city that experienced by 18.7 ha I year. Average speed of coastal line change of Bengkulu city is abrasion 
reached 1.97 meters / year. The areas that are changing the coastal line each year that Muara Sungai Hitam, Muara Kualo, Muara Sungai Jenggalu and Port of Pulau Baai. Bengkulu City Coastal line Changes may occur due to natural factors and human factors (Anthropogenic).

Keywords: Coastal line, remote sensing, landsat, abrasion, sedimentation.

\section{PENDAHULUAN}

Secara geografis Provinsi Bengkulu terletak memanjang sejauh 500 kilometer dengan pantai baratnya berhadapan langsung dengan lautan lepas (Sulistyo dkk, 1994). Hal ini pula yang menjadikan Kota Bengkulu sebagai daerah pesisir. Menurut Triatmodjo (1999) dalam Ladys dkk (2012), daerah pesisir adalah daerah darat di tepi laut yang masih mendapat pengaruh laut seperti pasang surut, angin laut dan perembesan air laut, sehingga dalam pengembangannya perlu memperhatikan ekosistem pesisir terutama kawasan pantai.

Nizam (1986) dalam Ladys dkk (2012) mengemukakan bahwa pantai sebagai tempat bertemunya lautan dan daratan merupakan tempat penghancuran energi gelombang. Kota Bengkulu merupakan salah satu wilayah yang pantainya berhadapan langsung dengan Samudera Hindia. Sebagian besar area di pantai Kota Bengkulu digunakan sebagai objek wisata pantai seperti yang ada di Pantai Jakat, jogging track yang ada di Pantai Panjang dan tempat labuh kapal seperti yang ada di Pulau Baai. Selain memiliki potensi yang besar di bidang wisata alam, secara geografis pantai Kota Bengkulu juga memiliki resiko tersendiri, karena berada di Samudera Hindia yang merupakan pertemuan antara lempeng Indo-Australia dan Eurasia yang sering terjadi gempa bumi.

Dengan adanya potensi dan juga resiko gempa bumi dari tahun ketahun di Kota Bengkulu, menyebabkan adanya perubahan pada morfologi Pantai Kota Bengkulu akibat dari kegiatan dan kejadian yang terjadi di Pantai Kota Bengkulu. Dari data selama 65 tahun, yaitu dari tahun 1926 sampai tahun 1991, telah terjadi erosi pantai sebesar 1,315,71 $\mathrm{Ha}$, di kawasan Kota Bengkulu setiap tahunnya terjadi erosi rata-rata sebesar 3,82 Ha. (Sulistyo dkk, 1994).

Menurut Pardjaman dan Handriani dalam Khairunissa (2010), perubahan garis pantai dapat terjadi akibat dari dua kejadian yaitu pengendapan material sedimen pantai (sedimentasi) dan pengikisan pantai (abrasi). Sedimentasi merupakan kondisi semakin majunya garis pantai akibat adanya penambahan material hasil endapan dari sungai dan laut, sedangkan abrasi adalah mundurnya garis pantai karena dinamika gerak air laut seperti gelombang dan hempasan ombak. Perubahan pantai juga bisa diakibatkan oleh penggalian, pengerukan, sedimentasi, reklamasi (penimbunan pantai), penanggulangan pantai, dan pengaturan pada aliran sungai (Bird dan Ongkosongo, 1980 dalam Nugroho 2012).

Upaya manusia dalam memanfaatkan kawasan pantai sering tidak dilandasi pemahaman yang baik tentang perilaku pantai. Akibatnya, berbagai masalah pantai bermunculan. Salah satunya adalah proses abrasi dan sedimentasi garis pantai (Awaliah, 2013). Proses abrasi dan sedimentasi garis 
pantai pada mulanya timbul secara alami, akan tetapi proses akan berlangsung lebih cepat jika pembangunan sarana kepentingan manusia tidak didasari dengan pengetahuan yang baik tentang perilaku proses dinamika perairan pantai, dalam hal ini perubahan garis pantai (Dewi, 2011 dalam Awaliah dkk, 2013).

Teknologi yang mudah dan cepat untuk pemantauan perubahan garis pantai adalah dengan menggunakan teknologi penginderaan jauh melalui perekaman citra satelit sebagai datanya. Salah satunya adalah dengan menggunakan data hasil perekaman citra Landsat (Land satellite) Taofiqurohman (2012). Oleh karena itu perlu dilakukan penelitian tentang perubahan garis pantai menggunakan teknologi pengindraan jauh untuk mengetahui kondisi aktual perubahan garis pantai yang terjadi di Kota Bengkulu.

\section{MATERI DAN METODE}

Penelitian ini telah dilaksanakan dari bulan Desember 2015 sampai bulan Februari 2016 di Pantai Kota Bengkulu. Alat yang digunakan dalam penelitian ini meliputi :

1. Perangkat lunak (software) yaitu ILWIS versi 3.4 Open dan Sofware SIG.

2. Perangkat keras (hardware), yaitu laptop dan seperangkat komputer

3. Data Digital Citra Satelit Landsat yang direkam dari tahun 2006 sampai tahun 2015 dengan Path 125 dan Row 63 untuk kawasan Kota Bengkulu.

4. Printer, untuk mencetak hasil penelitian.

5. ATK (pensil, pena, kertas HVS dan lain-lain).

6. Kamera digital untuk menggambarkan kondisi Pantai Kota Bengkulu saat ini.

Bahan yang digunakan dalam penelitian ini meliputi :

1. Data Citra Satelit Landsat-TM dalam format digital dengan Path 125 dan Row 63 untuk kawasan Kota Bengkulu untuk tahun 2006 hingga tahun 2011, kanal lengkap (full band) dengan format Geo Tiff.

2. Data Citra Satelit Landsat-7 ETM+ dalam format digital dengan Path 125 dan Row 63 untuk kawasan Kota Bengkulu untuk tahun 2012 dan tahun 2013, kanal lengkap (full band) dengan format Geo Tiff.

3. Data Citra Satelit Landsat-8 OLI dalam format digital dengan Path 125 dan Row 63 untuk kawasan Kota Bengkulu untuk tahun 2014 dan tahun 2015, kanal lengkap (full band) dengan format Geo Tiff.

Metode analisis data yang digunakan dalam penelitian ini yaitu yaitu analisis citra secara Visual (analog) dan analisis citra secara Digital. Menurut Sutanto (1986) dalam Handayani (2004) analisis citra secara visual meliputi 2 kegiatan yaitu penyadapan data citra dan penggunaan data tersebut untuk tujuan tertentu. Penyadapan data citra berupa pengenalan obyek dan elemen yang tergambar pada citra serta penyajiannya ke peta tematik tabel atau grafik. Analisis citra secara digital yaitu berupa koreksi radiometrik dan koreksi geometrik agar citra yang dihasilkan sesuai dengan keadaan sebenarnya di bumi. yaitu :

Metode pengolahan citra seri Landsat terdiri dari beberapa tahapan, 
1. Mendownload citra satelit dari situs http://earthexplorer.usgs.gov/ dimana citra yang dipilih dalam kondisi sangat bersih dan tidak ada gangguan awan pada segmen penelitian sehingga mempermudah analisis data.

2. Selanjutnya citra tersebut dipotong sesuai daerah yang akan dianalisis dan kemudian dilakukan koreksi geometrik.

3. Pembuatan komposit warna, dimaksudkan untuk mempermudah pengenalan gambaran dari pada obyek citra satelit. Kombinasi kanal RGB yang digunakan yaitu 451 untuk data citra Landsat 7 dan 564 untuk data citra Landsat 8. Kemudian citra yang telah dikomposit tersebut, disimpan dalam bentuk TIF agar dapat diolah lebih lanjut menggunakan Sofware SIG.

4. Lalu melakukan proses digitasi (on screen) citra RGB (Red Green Blue).

5. Kemudian hasil digitasi tersebut ditumpang susunkan (overlay) sehingga dapat terlihat dengan jelas mana daerah yang garis pantainya mengalami kemunduran ataupun penambahan daratan, untuk mengetahui perubahanperubahan garis pantai yang terjadi di Kota Bengkulu.

6. Analisa dan perhitungan dengan melakukan integrasi hasil digitasi setiap tahun sehingga dapat diketahui perubahannya baik perubahan akibat sedimentasi, erosi maupun karena faktor manusia.

\section{HASIL DAN PEMBAHASAN}

Pantai Kota Bengkulu merupakan pantai yang berhadapan langsung dengan Samudera Hindia jika dilihat dari kondisi geografis merupakan pantai berpasir dan termasuk kedalam pantai yang landai dan terdapat tiga sungai besar yang muaranya berhubungan langsung dengan laut lepas sehingga mendapat pengaruh dari gelombang laut yang cukup besar, sungai-sungai tersebut ialah Sungai Hitam, Sungai Air Bengkulu atau yang lebih dikenal dengan Kualo dan Sungai Jenggalu. Pada saat menganalisis data, diketahui terdapat 16 segmen yang mengalami perubahan garis pantai meskipun tidak semua segmen mengalami perubahan garis pantai. Adapun ke-16 segmen tersebut adalah Segmen 1 (Sungai Hitam), Segmen 2 (Bentiring), Segmen 3 (Muara Kualo), Segmen 4 (Pasar Bengkulu), Segmen 5 (Kampung Bali), Segmen 6 (Pondok Besi), Segmen 7 (Malabero), Segmen 8 (Pasar Baru), Segmen 9 (Pasar Melintang), Segmen 10 (Anggut Bawah), Segmen 11 (Kuala Lempuing), Segmen 12 (Muara Sungai Jenggalu), Segmen 13 (Bumi Ayu), Segmen 14 (Sumber Jaya), Segmen 15 (Pulau Baai), Segmen 16 (Teluk Sepang).

Hanya ada empat segmen yang mengalami perubahan garis pantai setiap tahunnya. Keempat segmen itu yaitu Segmen 1 (Muara Sungai Hitam), Segmen 3 (Muara Kualo), Segmen 12 (Muara Sungai Jenggalu) dan segmen 15 (Pulau Baai).

\section{Perubahan Garis Pantai Kota Bengkulu tahun 2006-2015}

Setelah dilakukannya pengolahan citra Landsat dari tahun 2006 sampai dengan tahun 2015, terjadi proses abrasi atau peristiwa mundurnya garis pantai dari kedudukan semula ke arah daratan dan proses sedimentasi atau peristiwa bertambahnya luas daratan akibat terkumpulnya sedimen-sedimen yang menjadi daratan (Setyandito, 2007). Perubahan garis pantai Kota Bengkulu terdapat pada Tabel 1. 
Tabel 1. Perubahan garis pantai kota bengkulu tahun 2006-2015

\begin{tabular}{cccc} 
Periode & Erosi (ha) & Sedimentasi (ha) & Perbedaan (ha) \\
\hline $\mathbf{2 0 0 6 - 2 0 0 7}$ & 19,151 & 3,661 & -15.49 \\
$\mathbf{2 0 0 7 - 2 0 0 8}$ & 14,378 & 23,254 & $+8,876$ \\
$\mathbf{2 0 0 8 - 2 0 0 9}$ & 4,027 & 19,73 & $+15,703$ \\
\hline $\mathbf{2 0 0 9 - 2 0 1 0}$ & 30,93 & 3,939 & $-26,991$ \\
\hline $\mathbf{2 0 1 0 - 2 0 1 1}$ & 7,362 & 29,55 & $+22,188$ \\
\hline $\mathbf{2 0 1 1 - 2 0 1 2}$ & 45,618 & 25,793 & $-19,825$ \\
\hline $\mathbf{2 0 1 2 - 2 0 1 3}$ & 7,803 & 7,311 & $-0,492$ \\
\hline $\mathbf{2 0 1 3 - 2 0 1 4}$ & 43,947 & 3,204 & $-40,743$ \\
\hline $\mathbf{2 0 1 4 - 2 0 1 5}$ & 1,546 & 51,906 & $+50,36$ \\
\hline Jumlah & 174,762 & 168,348 & $-6,414$ \\
\hline Rata-rata & 19,418 & 18,7 & 0,71 \\
\hline
\end{tabular}

Pada Tabel 1 abrasi tertinggi terjadi pada periode 2011-2012 sebesar 45,618 hektar sedangkan abrasi terendah terjadi pada periode 2014-2015 sebesar 1,546 hektar dengan rata-rata abrasi yang terjadi selama 10 tahun sebesar 19,418 hektar. Sedimentasi tertinggi terjadi pada periode 2014-2015 sebesar 51,906 hektar sedangkan sedimentasi terendah terjadi pada periode 2013-2014 sebesar 3,204 hektar dengan rata-rata sedimentasi yang terjadi selama 10 tahun sebesar 18,7 hektar. Rata-rata perubahan garis pantai Kota Bengkulu mengalami kemunduran ke arah daratan (abrasi) sebesar 0,71 hektar/tahun. Proses sedimentasi dan abrasi yang terjadi disepanjang Pantai Kota Bengkulu yang terjadi dari tahun 2006-2015 di 16 segmen dapat dilihat pada rincian sebagai berikut.

\section{a. Perubahan Garis Pantai tahun 2006-2007}

Adapun perubahan garis pantai yang terjadi pada tahun 2006-2007 dapat dilihat pada Gambar 1 berikut. 


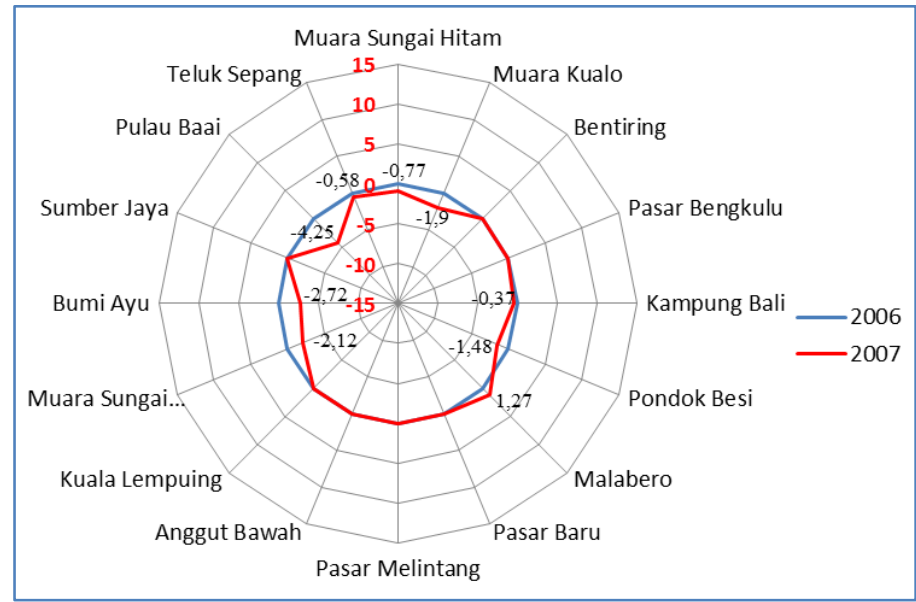

Gambar 1. Perubahan Garis Pantai Kota Bengkulu Periode 2006-2007

Pada Gambar 1 terlihat bahwa pada periode 2006-2007 perubahan garis pantai Kota Bengkulu yang bernilai negatif menandakan bahwa perubahan garis pantai berupa abrasi, sedangkan yang bernilai positif perubahan garis pantai berupa sedimentasi. Segmen yang paling besar mengalami perubahan garis pantai berupa abrasi adalah segmen 15 yang terdapat di Pulau Baai sebesar 4,25 hektar. Sedangkan untuk daerah yang mengalami sedimentasi terdapat pada segmen 7 yang berada di Malabero sebesar 1,27 hektar.

\section{b. Perubahan Garis Pantai tahun 2007-2008}

Adapun perubahan garis pantai yang terjadi pada tahun 2007-2008 dapat dilihat pada Gambar 2 berikut.

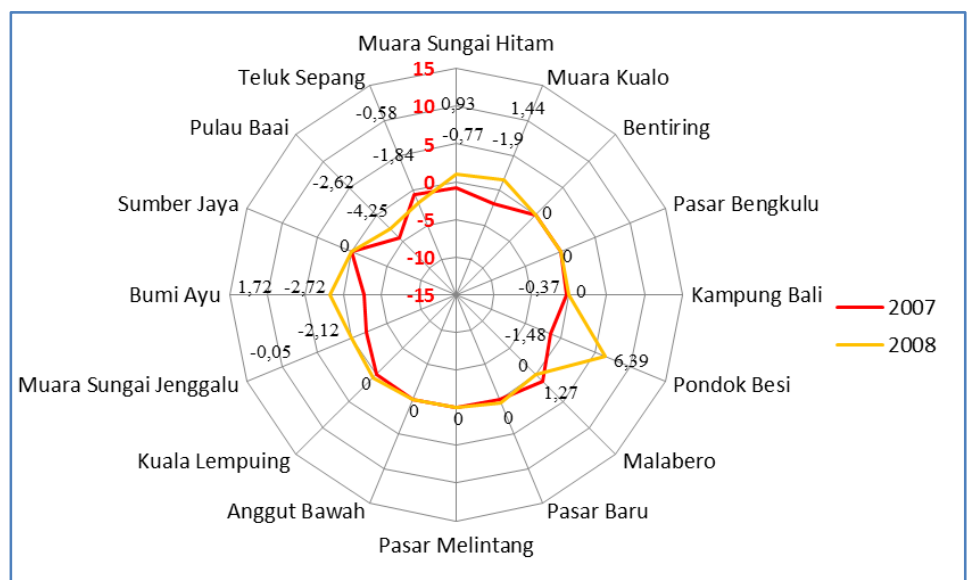

Gambar 2. Perubahan Garis Pantai Kota Bengkulu Periode 2007-2008

Pada Gambar 2 terlihat bahwa pada periode 2007-2008 perubahan garis pantai Kota Bengkulu yang bernilai negatif menandakan bahwa perubahan garis pantai berupa abrasi, sedangkan yang bernilai positif perubahan garis pantai berupa sedimentasi. Segmen yang paling besar mengalami perubahan garis pantai berupa abrasi adalah segmen 15 yang terdapat di Pulau Baai sebesar 4,25 hektar pada tahun 2007 dan pada tahun 2008 mengalami abrasi kembali sebesar 2,62 hektar. Sedangkan untuk daerah yang mengalami sedimentasi terdapat pada segmen 6 yang berada di Pondok Besi sebesar 6,39 hektar. 


\section{c. Perubahan Garis Pantai tahun 2008-2009}

Adapun perubahan garis pantai yang terjadi pada tahun 2008-2009 dapat dilihat pada Gambar 3 berikut.

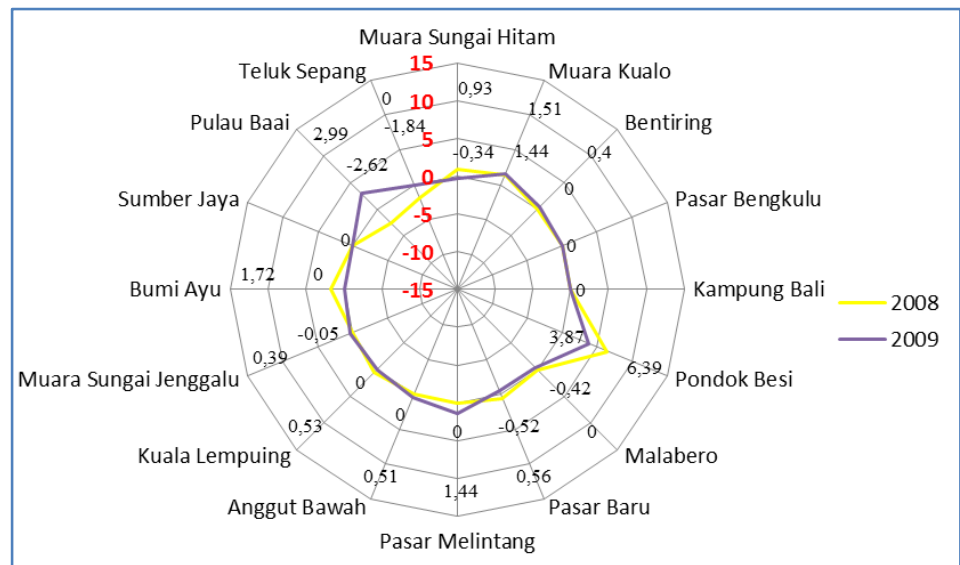

Gambar 3. Perubahan Garis Pantai Kota Bengkulu Periode 2008-2009

Pada Gambar 3 terlihat bahwa pada periode 2008-2009, segmen yang paling besar mengalami perubahan garis pantai berupa abrasi adalah segmen 15 yang terdapat di Pulau Baai sebesar 2,62 hektar pada tahun 2008. Sedangkan untuk daerah yang mengalami perubahan garis pantai berupa sedimentasi terdapat pada segmen 6 yang berada di Pondok Besi sebesar 6,39 hektar pada tahun 2008 dan pada tahun 2009 juga terjadi perubahan garis pantai berupa sedimentasi sebesar 3,87 hektar.

\section{d. Perubahan Garis Pantai tahun 2009-2010}

Adapun perubahan garis pantai yang terjadi pada tahun 2009-2010 dapat dilihat pada Gambar 4 berikut.

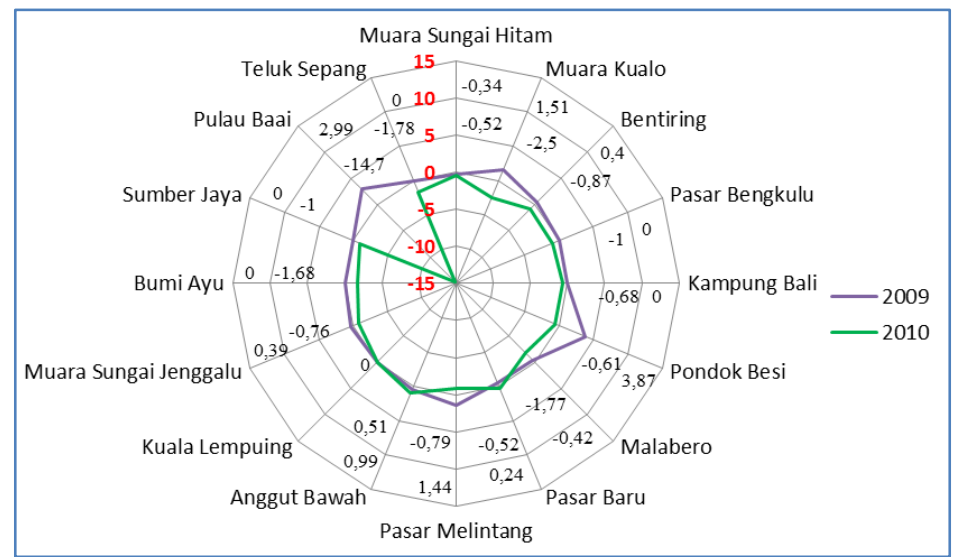

Gambar 4. Perubahan Garis Pantai Kota Bengkulu Periode 2009-2010

Pada Gambar 4 terlihat bahwa pada periode 2009-2010, segmen yang paling besar mengalami perubahan garis pantai berupa abrasi adalah segmen 15 yang terdapat di Pulau Baai sebesar 14,7 hektar pada tahun 2010. Sedangkan untuk daerah yang mengalami perubahan garis pantai berupa sedimentasi terdapat pada segmen 6 yang berada di Pondok Besi sebesar 3,87 hektar pada tahun 2009. 


\section{e. Perubahan Garis Pantai tahun 2010-2011}

Adapun perubahan garis pantai yang terjadi pada tahun 2010-2011 dapat dilihat pada Gambar 5 berikut.

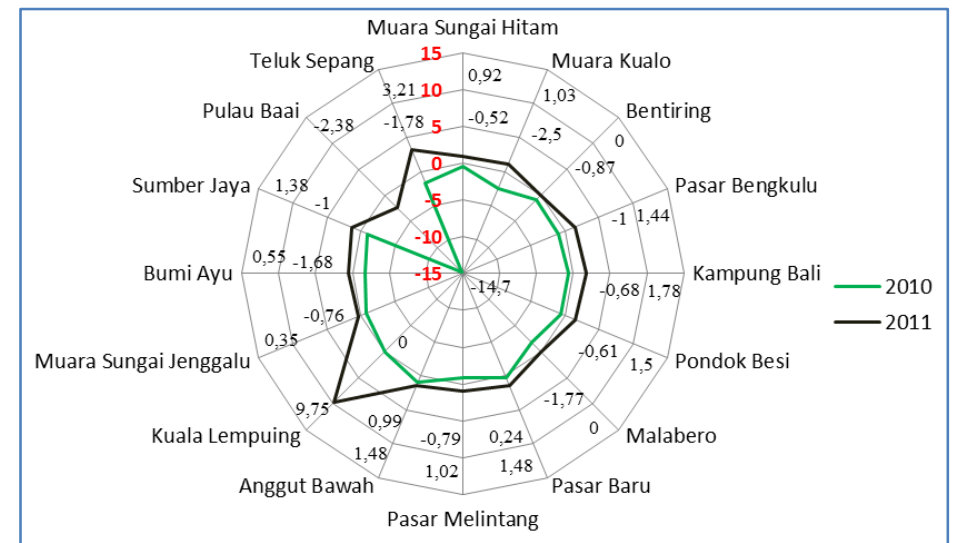

Gambar 5. Perubahan Garis Pantai Kota Bengkulu Periode 2010-2011

Pada Gambar 5 terlihat bahwa pada periode 2010-2011, segmen yang paling besar mengalami perubahan garis pantai berupa abrasi adalah segmen 15 yang terdapat di Pulau Baai sebesar 14,7 hektar pada tahun 2010 dan pada tahun 2011 juga terjadi perubahan garis pantai berupa abrasi sebesar 2,38 hektar. Sedangkan untuk daerah yang mengalami perubahan garis pantai berupa sedimentasi terdapat pada segmen 11 yang berada di Kuala Lempuing sebesar 9,75 hektar pada tahun 2011.

\section{f. Perubahan Garis Pantai tahun 2011-2012}

Adapun perubahan garis pantai yang terjadi pada tahun 2011-2012 dapat dilihat pada Gambar 6 berikut.

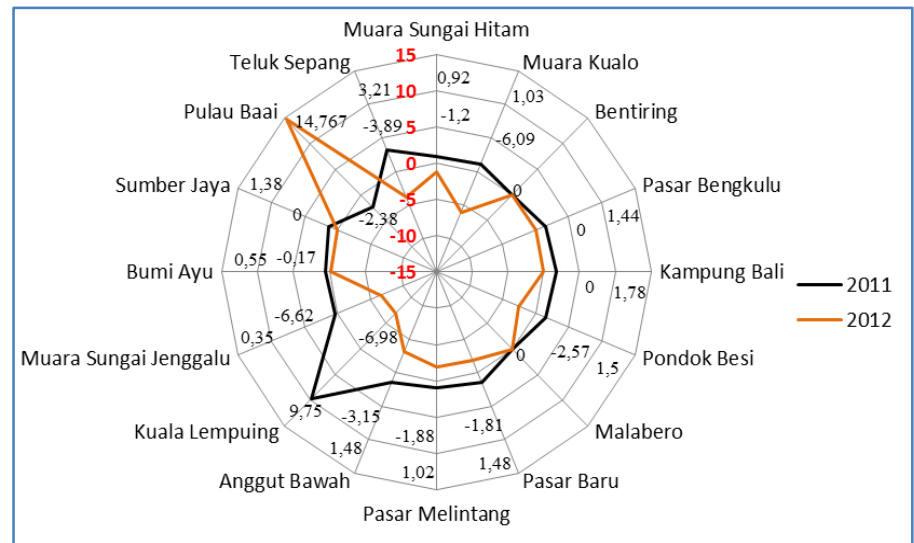

Gambar 6. Perubahan Garis Pantai Kota Bengkulu Periode 2011-2012

Pada Gambar 6 terlihat bahwa pada periode 2011-2012, segmen yang paling besar mengalami perubahan garis pantai berupa abrasi adalah segmen 11 yang terdapat di Kuala Lempuing sebesar 6,98 hektar pada tahun 2012. Sedangkan untuk daerah yang mengalami perubahan garis pantai berupa sedimentasi terdapat pada segmen 15 yang berada di Pulau Baai sebesar 14,76 hektar pada tahun 2012. 


\section{g. Perubahan Garis Pantai tahun 2012-2013}

Adapun perubahan garis pantai yang terjadi pada tahun 2012-2013 dapat dilihat pada Gambar 8 berikut.

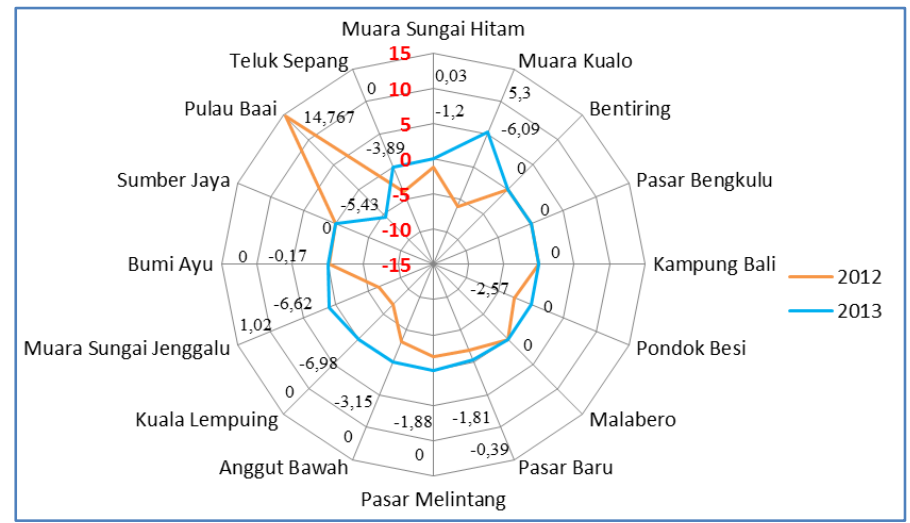

Gambar 7. Perubahan Garis Pantai Kota Bengkulu Periode 2012-2013

Pada Gambar 7. terlihat bahwa pada periode 2012-2013, segmen yang paling besar mengalami perubahan garis pantai berupa abrasi adalah segmen 11 yang terdapat di Kuala Lempuing sebesar 6,98 hektar pada tahun 2012. Sedangkan untuk daerah yang mengalami sedimentasi terdapat pada segmen 15 yang berada di Pulau Baai sebesar 14,76 hektar pada tahun 2012 dan di segmen 2 yang berada di Muara Kualo juga mengalami perubahan garis pantai berupa sedimentasi yang tinggi sebesar 5,3 hektar pada tahun 2013.

\section{h. Perubahan Garis Pantai tahun 2013-2014}

Adapun perubahan garis pantai yang terjadi pada tahun 2013-2014 dapat dilihat pada Gambar 8 berikut.

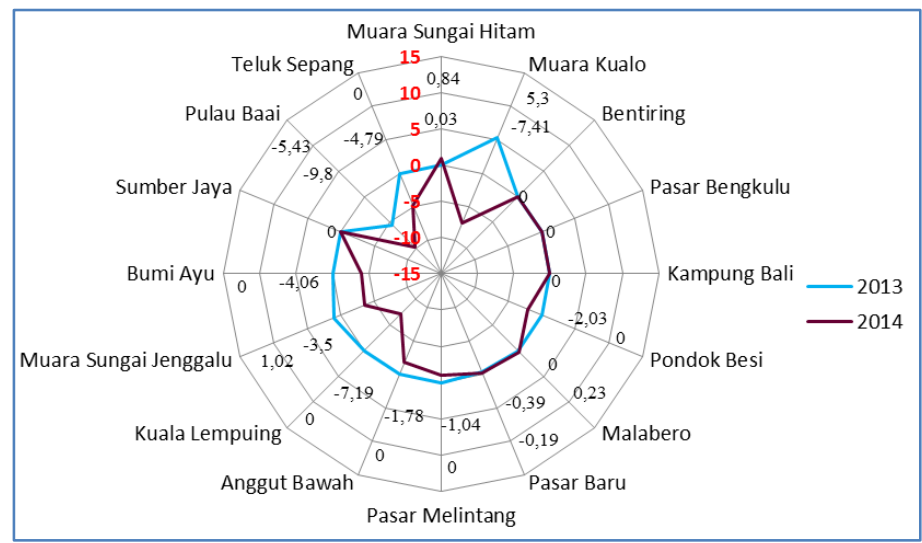

Gambar 8. Perubahan Garis Pantai Kota Bengkulu Periode 2013-2014

Pada Gambar 8 terlihat bahwa pada periode 2013-2014, segmen yang paling besar mengalami perubahan garis pantai berupa abrasi adalah segmen 15 yang terdapat di Pulau Baai sebesar 9,8 hektar pada tahun 2014. Sedangkan untuk daerah yang mengalami perubahan garis pantai berupa sedimentasi terdapat pada segmen 2 yang berada di Muara Kualo sebesar 5,3 hektar pada tahun 2013. 


\section{i. Perubahan Garis Pantai tahun 2014-2015}

Adapun perubahan garis pantai yang terjadi pada tahun 2014-2015 dapat dilihat pada Gambar 10 berikut.

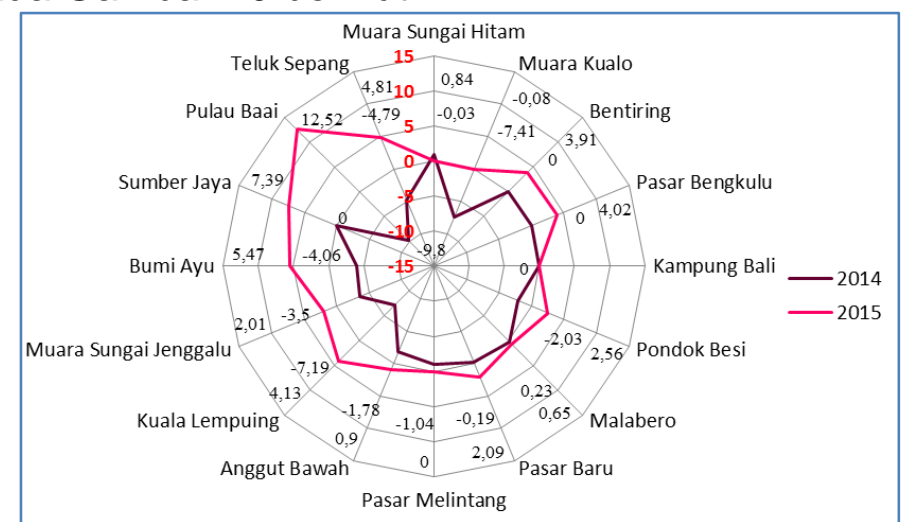

Gambar 9. Perubahan Garis Pantai Kota Bengkulu Periode 2014-2015

Pada Gambar 9 terlihat bahwa pada periode 2014-2015, segmen yang paling besar mengalami perubahan garis pantai berupa abrasi adalah segmen 15 yang terdapat di Pulau Baai sebesar 9,8 hektar pada tahun 2014. Sedangkan untuk daerah yang mengalami perubahan garis pantai berupa sedimentasi terdapat pada segmen 15 juga yaitu di Pulau Baai sebesar 12,52 hektar pada tahun 2015.

Berdasarkan hasil penelitian ini, hampir disepanjang pantai Kota Bengkulu mengalami perubahan, namun tidak seluruh segmen mengalami perubahan setiap tahun. Terdapat empat segmen yang mengalami perubahan garis pantai setiap tahunnya, yaitu Muara Sungai Hitam, Muara Kualo, Muara Muara Jenggalu dan Pelabuhan Pulau Baai. Ketiga muara sungai tersebut termasuk kedalam muara yang didominasi gelombang laut karena gelombang yang datang tegak lurus dengan muara sungai (Triatmodjo, 2014).

Jika dilihat dari segi geologi, Pantai Kota Bengkulu berhadapan langsung dengan Samudera Hindia tanpa adanya pulau-pulau kecil yang mengelilinginya. Hal ini menyebabkan gelombang laut yang datang akan langsung mengarah ke Pantai Kota Bengkulu. Gelombang laut Pantai Kota Bengkulu tergolong cukup tinggi (1-1,5 meter) dengan arah pergerakan anginnya langsung mengarah menuju Kota Bengkulu (BMKG, 2016). Gelombang besar yang terjadi pada pantai berpasir dapat menyebabkan terjadinya angkutan sedimen (pasir) baik dalam arah tegak lurus maupun sepanjang pantai. Semakin besar gelombang, semakin besar angkutan sedimen dan semakin banyak sedimen yang mengendap di muara (Triatmodjo, 2014).

\section{KESIMPULAN DAN SARAN}

Luas rata-rata garis pantai Kota Bengkulu secara keseluruhan bersifat abrasi sebesar 6,414 hektar dengan rata-rata abrasi setiap tahun sebesar 19,418 hektar dan sedimentasi rata-rata setiap tahunnya sebesar 18,7 hektar. Lokasi yang potensial mengalami abrasi maupun sedimentasi yang cepat adalah Muara Sungai Hitam, Muara Kualo, Muara Sungai Jenggalu dan Pelabuhan Pulau Baai. Untuk itu sebaiknya pemerintah segera melakukan 
tindakan antisipasi terhadap perubahan garis pantai yang terjadi, sehingga dapat mengurangi resiko yang ada.

\section{DAFTAR PUSTAKA}

Arief, M., Winarso G., dan Prayogo T. 2011. Kajian Perubahan Garis Pantai Menggunakan Data Satelit Landsat Di Kabupaten Kendal. Jurnal Penginderaan Jauh. V (8) : $71-80$

Awaliah, O.W., Sakka, dan Hamzah, M.A. 2013. Modul Perubahan Garis Pantai Dengan Metode One-Line Model (Studi Kasus : Pantai Mangarabombang - Galesong Selatan, Kabupaten Takaliar). Universitas Hasanudin

BMKG. 2016. Prakiraan Tinggi Gelombang. http://www.bmkg.go.id/BMKG_Pusat/Informasi_Cuaca/Maritim_Cuaca_P elayaran/Prakiraan_Tinggi_Gelombang.bmkg diakses pada tanggal 15 Februari 2016.

Khairunnisa, A. 2010. Tinjauan pustaka dinamika pantai. http://nizcha0804.blogspot.com-/2010/02/tinjauan-pustaka-dinamikapantai.html. Diakses tanggal 3 Desember 2015.

Ladys, M., Surbakti, H., dan Hartoni. 2012. Penentuan Perubahan Garis Pantai Dengan Teknologi Penginderaan Jauh dan Model Numerik di Kabupaten Batang Provinsi Jawa Tengah. Jurnal Maspari. V (4) No. 2 : 231 - 237.

Nugroho, S.H. 2012. Perubahan Karakteristik Garis Pantai Di Kawasan Wisata Pantai Alam Indah, Kota Tegal. Oseanologi dan Limnologi di Indonesia, 34 (1) : 19-26.

Setyandito, O. 2007. Analisa Abrasi dan Perubahan Garis Pantai Pada Pantai Pasir Buatan dan Sekitarnya di Takisung Provinsi Kalimantan Selatan. Jurnal Teknik Sipil. 7(3) : 224-235.

Sugiarto, Dwi Putro, 2013. Cara Download Landsat 8 Gratis Melalui Earthexplorer USGS. https://tnrawku.wordpress.com/2013/06/11/caradownload-landsat-8-gratis-melalui-earthexplorer-usgs/, diunduh pada tanggal 13 April 2015 pukul 20.14 WIB.

Sulistyo, B., N.M, Syamsu dan I, G, Made. 1994 Studi Penelitian Perubahan Garis Pantai di Kawasan Kotamadia Bengkulu. Laporan Penelitian, Direktorat Penelitian dan Pengabdian pada Masyarakat, Direktorat Jenderal Pendidikan Tinggi, Departemen Pendidikan dan Kebudayaan.

Taofiqurohman, A., dan Azis, M. F. 2012. Analisis Spasial Perubahan Garis Pantai di Pesisir Kabupaten Subang Jawa Barat. Jurnal IImu dan Teknologi Kelautan Tropis, 4 (1) : $280-289$

Triatmodjo, B. 2014. Perencanaan Bangunan Pantai. Yogyakarta : Beta Offset. 